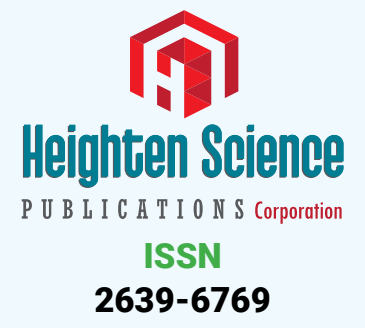

*Address for Correspondence: Ahmed RG Division of Anatomy and Embryology, Zoology Department, Faculty of Science, Beni-Suef University, Beni-Suef, Egypt, Tel/Fax: 002-01091471828; Email: ahmedragab08@gmail.com

Submitted: 16 December 2017 Approved: 26 December 2017 Published: 27 December 2017

Copyright: @2 2017 Ahmed RG. This is an open access article distributed under the Creative Commons Attribution License, which permits unrestricted use, distribution, and reproduction in any medium, provided the original work is properly cited
Short Communication

\section{Maternal thyroid dysfunction and neonatal cardiac disorders}

\author{
Ahmed RG* \\ Division of Anatomy and Embryology, Zoology Department, Faculty of Science, Beni-Suef \\ University, Beni-Suef, Egypt
}

\section{Communication}

The normal levels of thyroid hormones (THs; thyroxine, T4 \& 3,5,3'-triiodo-Lthyronine, T3) are necessary for the normal development [1-48], particularly the fetal and neonatal cardiac growth and development [49]. The actions of THs are facilitated genomically by thyroid receptors (TRs, $\alpha$ and $\beta$ ) and non-genomically at the plasma membrane, in the cytoplasm and in cellular organelles [4,49-55], by stimulation of $\mathrm{Na}+, \mathrm{K}+, \mathrm{Ca} 2+$ and glucose transport, activation of protein kinase $\mathrm{C}$ (PKC), protein kinase $\mathrm{A}(\mathrm{PKA})$ and mitogen activated and protein kinase (ERK/MAPK) [4]. In addition, the transport of $\mathrm{T} 4$ and $\mathrm{T} 3$ in and out of cells is controlled by several classes of transmembrane TH-transporters (THTs) [56], including members of the organic anion transporter family (OATP), L-type amino acid transporters (LATs), Na+/Taurocholate cotransporting polypeptide (NTCP), and monocarboxylate transporters (MCTs) $[4,49,57,58]$. Adding additional complexity, the metabolism of T4 and T3 is regulated by 3 selenoenzyme iodothyronine deiodinases (Ds: D1, D2 and D3) [59-61]. On the other hand, the congenital hypothyroidism can cause the following [49,62-64], (1) congenital heart diseases; (2) diastolic hypertension; (3) reduced cardiac output, stroke volume and a narrow pulse pressure; (4) dilatation and overt heart failure; (5) elevation in the systemic vascular resistance [65-68]. Similarly, the chronic hyperthyroidism can cause the following [49,64]: (1) cardiac hypertrophy; (2) increase in the cardiomyocyte (CM) length rather than width; (3) noticeable diminution in systemic vascular resistance; (4) elevation in the cardiac contractility; (5) systolic hypertension; (6) increase in the cardiac output, venous volume return, blood volume and pulse pressure; and (7) reduction in the systemic vascular resistance $[49,69]$. T3-therapy can induce DNA synthesis and cardiomyocyte proliferation, and improve the cardiac contractility; though, this action is as still unidentified [49,70-74].

On the basis of these data, it can be reported that the T3 may stimulate the cardiac contractility and stimulate the hemodynamic changes (blood pressure, blood volume and heart rate) during the prenatal and postnatal periods. Additional studies are necessary to delineate the likely relations with human health. Future examinations are necessary to explore the multidirectional actions of TH-therapy in the maternal and neonatal cardiovascular diseases.

\section{References}

1. El-bakry AM, El-Ghareeb AW, Ahmed RG. Comparative study of the effects of experimentally-induced hypothyroidism and hyperthyroidism in some brain regions in albino rats. Int J Dev Neurosci. 2010; 28: 371-389. Ref.: https://goo.gl/6UK4XT

2. Ahmed RG. Perinatal TCDD exposure alters developmental neuroendocrine system. Food Chem Toxicology. 2011; 49: 1276-1284. Ref.: https://goo.gl/U8B5dK 
3. Ahmed RG. Maternal-newborn thyroid dysfunction. In the Developmental Neuroendocrinology, pp. 1-369. Ed R.G. Ahmed. Germany: LAP LAMBERT Academic Publishing GmbH \& Co KG. 2012.

4. Ahmed RG. Maternal-fetal thyroid interactions, Thyroid Hormone, Dr. N.K. Agrawal (Ed.), ISBN: 978953-51-0678-4, In Tech Open Access Publisher, Chapter 5. 2012; 125-156.

5. Ahmed RG. Early weaning PCB 95 exposure alters the neonatal endocrine system: thyroid adipokine dysfunction. J Endocrinol. 2013; 219: 205-215. Ref.: https://goo.gl/1A4tfR

6. Ahmed RG. Do PCBs modify the thyroid-adipokine axis during development?. Annals Thyroid Res. 2014; 1: 11-12. Ref.: https://goo.gl/qmTkfb

7. Ahmed RG. Chapter 1: Hypothyroidism and brain development. In advances in hypothyroidism treatment. Avid Science Borsigstr. 9, 10115 Berlin, Berlin, Germany. Avid Science Publications leve 6, Melange Towers, Wing a, Hitec City, Hyderabad, Telangana, India. 2015; 1-40.

8. Ahmed RG. Hypothyroidism and brain developmental players. Thyroid Research J. 2015; 8: 1-12 Ref.: https://goo.gl/r9wAcW

9. Ahmed RG. Editorials and Commentary: Maternofetal thyroid action and brain development. $\mathrm{J}$ of Advances in Biology. 2015; 7: 1207-1213.

10. Ahmed RG. Developmental adipokines and maternal obesity interactions. J of Advances in Biology. 2015; 7: 1189-1206.

11. Ahmed RG. Maternal bisphenol A alters fetal endocrine system: Thyroid adipokine dysfunction. Food Chem Toxicology. 2016; 95: 168-174. Ref.: https://goo.gl/Kb9Zpv

12. Ahmed RG. Gestational dexamethasone alters fetal neuroendocrine axis. Toxicology Letters. 2016 258: 46-54. Ref.: https://goo.gl/t5nFKs

13. Ahmed RG. Maternal iodine deficiency and brain disorders. Endocrinol. Metab. Syndr. 2016; 5: 223.

14. Ahmed RG. Neonatal polychlorinated biphenyls-induced endocrine dysfunction. Ann Thyroid Res. 2016; 2: 34-35. Ref.: https://goo.gl/iSJDzP

15. Ahmed RG. Developmental thyroid diseases and GABAergic dysfunction. EC Neurology. 2017; 8: 2-4 Ref.: https://goo.gl/A1nmPp

16. Ahmed RG. Hyperthyroidism and developmental dysfunction. Arch Med. 2017; 9: 4. Ref.: https://goo.gl/kcSWVK

17. Ahmed RG. Anti-thyroid drugs may be at higher risk for perinatal thyroid disease. EC Pharmacology and Toxicology. 2017; 4: 140-142. Ref.: https://goo.gl/xoYft6

18. Ahmed RG. Perinatal hypothyroidism and cytoskeleton dysfunction. Endocrinol Metab Syndr. 2017; 6: 271.

19. Ahmed RG. Developmental thyroid diseases and monoaminergic dysfunction. Advances in Applied Science Research. 2017; 8; 1-10. Ref.: https://goo.gl/2La731

20. Ahmed RG. Hypothyroidism and brain development. J Anim Res Nutr. 2017; 2: 13.

21. Ahmed RG. Antiepileptic drugs and developmental neuroendocrine dysfunction: Every why has A Wherefore. Arch Med. 2017; 9: 2. Ref.: https://goo.gl/xsfSk4

22. Ahmed RG. Gestational prooxidant-antioxidant imbalance may be at higher risk for postpartum thyroid disease. Endocrinol Metab Syndr. 2017; 6: 279. Ref.: https://goo.gl/vPoiEo

23. Ahmed RG. Synergistic actions of thyroid-adipokines axis during development. Endocrinol Metab Syndr. 2017; 6: 280. Ref.: https://goo.gl/YHXnYv

24. Ahmed RG. Thyroid-insulin dysfunction during development. International Journal of Research Studies in Zoology. 2017; 3: 73-75. Ref.: https://goo.gl/AXrH7c

25. Ahmed RG. Developmental thyroid diseases and cholinergic imbalance. International Journal of Research Studies in Zoology. 2017; 3: 70-72. Ref.: https://goo.gl/bc5xsE

26. Ahmed RG. Thyroid diseases and developmental adenosinergic imbalance. Int J Clin Endocrinol. 2017; 1: 053-055

27. Ahmed RG. Maternal anticancer drugs and fetal neuroendocrine dysfunction in experimental animals. Endocrinol Metab Syndr. 2017; 6: 281.

28. Ahmed RG. Gestational dexamethasone may be at higher risk for thyroid disease developing peripartum. Open Journal of Biomedical \& Life Sciences (Ojbili). 2017; 3: 1-6. Ref.: https://goo.gl/xBLL6B 
29. Ahmed RG. Deiodinases and developmental hypothyroidism. EC Nutrition. 2017; 11: 183-185.

30. Ahmed RG. Maternofetal thyroid hormones and risk of diabetes. Int. J. of Res. Studies in Medical and Health Sciences. 2017; 2: 18-21.

31. Ahmed RG. Association between hypothyroidism and renal dysfunctions. Int. J. of Res. Studies in Medical and Health Sciences. 2017; 2: 1-4.

32. Ahmed RG. Maternal hypothyroidism and lung dysfunction. Int J of Res. Studies in Medical and Health Sciences (in press). 2017.

33. Ahmed OM, El-Gareib AW, El-bakry AM, Abd El-Tawab SM, Ahmed RG. Thyroid hormones states and brain development interactions. Int J Dev Neurosci. 2008; 26: 147-209. Ref.: https://goo.gl/mjvT6f

34. Ahmed OM, Abd El-Tawab SM, Ahmed RG. Effects of experimentally induced maternal hypothyroidism and hyperthyroidism on the development of rat offspring: I- The development of the thyroid hormones-neurotransmitters and adenosinergic system interactions. Int J Dev Neurosci. 2010; 28: 437-454. Ref.: https://goo.gl/Rpj7ZT

35. Ahmed OM, Ahmed RG. Hypothyroidism. In A New Look At Hypothyroidism. Dr. D. Springer (Ed.) ISBN: 978-953-51-0020-1), In Tech Open Access Publisher. 2012; 1-20.

36. Ahmed RG, Incerpi S, Ahmed F, Gaber A. The developmental and physiological interactions between free radicals and antioxidant: Effect of environmental pollutants. J of Natural Sci Res. 2013; 3: 74110. Ref.: https://goo.gl/v8cpJ4

37. Ahmed RG, Davis PJ, Davis FB, De Vito P, Farias RN, et al. Nongenomic actions of thyroid hormones: from basic research to clinical applications. An update. Immunology, Endocrine \& Metabolic Agents in Medicinal Chemistry. 2013; 13: 46-59. Ref.: https://goo.gl/QbdSdA

38. Ahmed RG, El-Gareib AW. Lactating PTU exposure: I- Alters thyroid-neural axis in neonatal cerebellum. Eur J of Biol and Medical Sci Res. 2014; 2; 1-16. Ref.: https://goo.gl/HhpnXZ

39. Ahmed RG, Abdel-Latif M, Mahdi E, El-Nesr K. Immune stimulation improves endocrine and neural fetal outcomes in a model of maternofetal thyrotoxicosis. Int Immunopharmacol. 2015; 29: 714-721. Ref.: https://goo.gl/2cBoz4

40. Ahmed RG, Abdel-Latif M, Ahmed F. Protective effects of GM-CSF in experimental neonatal hypothyroidism. International Immunopharmacology. 2015; 29: 538-543. Ref.: https://goo.gl/YWLi5W

41. Incerpi S, Hsieh MT, Lin HY, Cheng GY, De Vito $P$, et al. Thyroid hormone inhibition in L6 myoblasts of IGF-I-mediated glucose uptake and proliferation: new roles for integrin avß3. Am J Physiol Cell Physiol. 2014; 307: 150-161. Ref.: https://goo.gl/yVw6qM

42. Van Herck SLJ, Geysens S, Bald E, Chwatko G, Delezie E, et al. Maternal transfer of methimazole and effects on thyroid hormone availability in embryonic tissues. Endocrinol. 2013; 218: 105-115. Ref.: https://goo.gl/ftwPZe

43. Candelotti E, De Vito P, Ahmed RG, Luly P, Davis PJ, et al. Thyroid hormones crosstalk with growth factors: Old facts and new hypotheses. Agents in Med Chem. 2015; 15: 71-85. Ref.: https://goo.gl/oK8EEZ

44. Ahmed RG, El-Gareib AW, Incerpi S. Lactating PTU exposure: II- Alters thyroid-axis and prooxidantantioxidant balance in neonatal cerebellum. Int Res J of Natural Sciences. 2014; 2: 1-20.

45. De Vito P, Candelotti E, Ahmed RG, Luly P, Davis PJ, et al. Role of thyroid hormones in insulin resistance and diabetes. Immun Endoc \& Metab Agents in Med Chem. 2015; 15: 86-93.

46. El-Ghareeb AA, El-Bakry AM, Ahmed RG, Gaber A. Effects of zinc supplementation in neonatal hypothyroidism and cerebellar distortion induced by maternal carbimazole. Asian Journal of Applied Sciences. 2016; 4: 1030-1040

47. Ahmed RG, El-Gareib AW. Maternal carbamazepine alters fetal neuroendocrine-cytokines axis. Toxicology. 2017; 382: 59-66. Ref.: https://goo.gl/x3otPF

48. Gigena N, Alamino VA, Montesinos MM, Nazar M, Louzada RA, et al. Dissecting thyroid hormone transport and metabolism in dendritic cells. J Endocrinology. 2017; 232: 337-350. Ref.: https://goo.gl/GH8cil

49. Li M, lismaa SE, Naqvi N, Nicks A, Husain A, et al. Thyroid hormone action in postnatal heart development. Stem Cell Res. 2014; 13: 582-591. Ref.: https://goo.gl/7TDRLa

50. Davis PJ, Davis FB. Nongenomic actions of thyroid hormone on the heart. Thyroid. 2002; 12: 459466. Ref.: https://goo.gl/fzHFo1 
51. Mai W, Janier MF, Allioli N, Quignodon L, Chuzel T, et al. Thyroid hormone receptor alpha is a molecular switch of cardiac function between fetal and postnatal life. Proc Natl Acad Sci USA. 2004; 101: 10332-10337. Ref.: https://goo.gl/YWwCgT

52. Incerpi S. Thyroid hormones: rapid reply by surface delivery only. Endocrinol. 2005; 146: 2861-2863. Ref.: https://goo.gl/kzk3gw

53. Incerpi S. Nongenomic effects of thyroid hormones in skeletal muscle and central nervous system: from zebrafish to man. Immun Endocr Metab Agents Med Chem. 2011; 11: 150-151.

54. Davis PJ, Lin HY, Mousa SA, Luidens MK, Hercbergs AA, et al. Overlapping nongenomic and genomic actions of thyroid hormone and steroids. Steroids. 2011; 76: 829-833. Ref.: https://goo.gl/xhYDxX

55. De Vito P, Incerpi S, Pedersen JZ, Luly P, Davis FB, et al. Thyroid hormones as modulators of immune activities at the cellular level. Thyroid. 2011; 21: 879-890. Ref.: https://goo.gl/f2DzC7

56. Incerpi S, De Vito $\mathrm{P}$, Luly $\mathrm{P}$, Spagnuolo $\mathrm{S}$, Leoni S. Short-term effects of thyroid hormones and 3,5-diiodothyronine on membrane transport systems in chick embryo hepatocytes. Endocrinol. 2002; 143: 1660-1668. Ref.: https://goo.gl/nsybXu

57. Suzuki T, Abe T. Thyroid hormone transporters in the brain. Cerebellum. 2008; 75-83. Ref.: https://goo.gl/RdPN7X

58. Visser WE, Friesema EC, Jansen J, Visser TJ. Thyroid hormone transport in and out of cells. Trends Endocrinol Metab. 2008; 19: 50-56. Ref.: https://goo.gl/GEjKt9

59. Zoeller RT, Tan SW, Tyl RW. General background on the hypothalamic-pituitary-thyroid (HPT) axis. Crit Rev Toxicol. 2007; 37: 11-53. Ref.: https://goo.gl/nzGzdR

60. Kress E, Samarut J, Plateroti M. Thyroid hormones and the control of cell proliferation or cell differentiation: paradox or duality? Mol. Cell. Endocrinol. 2009; 313: 36-49.

61. Brent GA. Mechanisms of thyroid hormone action. J Clin Invest. 2012; 122: 9035-9043.

62. Legrand J. Thyroid hormone effects on growth and development. In: Henneman, G. (Ed.), Thyroid Hormone Metabolism. Marcel Dekker, Rotterdam. The Netherlands. 1986.

63. Olivieri A, Stazi MA, Mastroiacovo P, Fazzini C, Medda E, et al. A population-based study on the frequency of additional congenital malformations in infants with congenital hypothyroidism: data from the Italian Registry for Congenital Hypothyroidism (1991-1998). J Clin Endocrinol Metab. 2002; 87: 557-562. Ref.: https://goo.gl/UjYWd8

64. Maillet $\mathrm{M}$, Van Berlo JH, Molkentin JD. Molecular basis of physiological heart growth: fundamental concepts and new players. Nat Rev Mol Cell Biol. 2013; 14: 38-48. Ref.: https://goo.gl/cgH6tR

65. Bengel FM, Lehnert J, Ibrahim T, Klein C, Bulow HP, et al. Cardiac oxidative metabolism, function and metabolic performance in mild hyperthyroidism: a noninvasive study using positron emission tomography and magnetic resonance imaging. Thyroid. 2003; 13: 471-477. Ref.: https://goo.gl/pVJqqd

66. Danzi S, Klein I. Thyroid hormone and blood pressure regulation. Curr Hypertens Rep. 2003; 5: 513520. Ref.: https://goo.gl/Cs3tiq

67. Biondi B, Palmieri EA, Lombardi G, Fazio S. Effects of thyroid hormone on cardiac function: the relative importance of heart rate, loading conditions, and myocardial contractility in the regulation of cardiac performance in human hyperthyroidism. J Clin Endocrinol Metab. 2002; 87: 968-974. Ref.: https://goo.gl/1N61vi

68. Kiss E, Jakab G, Kranias EG, Edes I. Thyroid hormone induced alterations in phospholamban protein expression. Regulatory effects on sarcoplasmic reticulum $\mathrm{Ca} 2+$ transport and myocardial relaxation. Circ Res. 1994; 75: 245-251. Ref.: https://goo.gl/1Gmj9E

69. Klein I, Ojamaa K. Thyroid hormone and the cardiovascular system. N Engl J Med. 2001; 344: 501 509. Ref.: https://goo.gl/p7tTLr

70. Ledda-Columbano GM, Molotzu F, Pibiri M, Cossu C, Perra A, et al. Thyroid hormone induces cyclin D1 nuclear translocation and DNA synthesis in adult rat cardiomyocytes. FASEB J. 2006; 20: 87-94. Ref.: https://goo.gl/uVfCBC

71. Janssen R, Zuidwijk M, Muller A, Mulders J, Oudejans CB, et al. Cardiac expression of deiodinase type 3 (Dio3) following myocardial infarction is associated with the induction of a pluripotency microRNA signature from the Dlk1-Dio3 genomic region. Endocrinology. 2013; 154: 1973-1978. Ref.: https://goo.gl/bD8tE1 
72. Naqvi N, Li M, Calvert JW, Tejada T, Lambert JP, et al. A proliferative burst during preadolescence establishes the final cardiomyocyte number. Cell. 2014; 157: 795-807. Ref.: https://goo.gl/HkD6Yd

73. Ahmed OM, Ahmed RG, El-Gareib AW, El-Bakry AM, Abd El-Tawaba SM. Effects of experimentally induced maternal hypothyroidism and hyperthyroidism on the development of rat offspring: I-The developmental pattern of neurons in relation to oxidative stress and antioxidant defense system. Int J Dev Neurosci. 2012; 30: 517-537. Ref.: https://goo.gl/j34VBN

74. Ahmed RG, Incerpi S. Gestational doxorubicin alters fetal thyroid-brain axis. Int J Devl Neuroscience. 2013; 31: 96-104. Ref.: https://goo.gl/2jeKKj 